\title{
Empowerment of Urban Women Through Local Food Processing Cooperatives in Alamata Town, Tigray, Ethiopia
}

\author{
Nega Gebreegzi (MA) Dr. Abadi T/Haimanot (associate professor)
}

\begin{abstract}
Cooperative is one of the strategies to achieve development and reduce poverty. Empirical studies on urban women empowerment via small scale local food processing cooperatives have little attention in business researches of developing countries. This study focuses on empowerment of urban women through local food processing cooperatives in Alamata town, Tigray, Ethiopia. Based on data collected from a sample of 150 members and customers of local food processing cooperatives, the researcher used descriptive statistics for analyzing attitude and competency of women in local food processing cooperatives, factor analysis for analyzing and identifying factors affecting local food processing cooperatives, and logistic regression for analyzing empowerment indicators of urban women in local food processing cooperatives. In addition, logistic regression model was also used to analyze empowerment indicators in the cooperatives. The majority of cooperative members have good attitude and competency towards small scale local food processing cooperatives that may have a positive impact on empowerment of urban women. Some variables such as family size and education, age and livestock ownership were negatively correlated. Factor analysis identified that economic dependency, lack of access to center of production, access to market, competency gap, access to credit, and health care difficulties were the challenges that participants faced. Therefore, formation of market network, evenly distributed nutritional trainings, special attention to women at older ages, opportunities for center of production, revision of banks and microfinance institutions' prerequisites on provision of loan, were the recommendations of this study. Results of this study indicated over all progresses with limitations expressed above. Local food processing cooperatives were safeguard for empowerment of urban women at the grass root level. This was because they were not much capital intensive, rather profitable in limited capital in urban areas.
\end{abstract}

Keywords: - Empowerment, women, food, cooperative, Alamata, Tigray, Ethiopia

DOI: $10.7176 / \mathrm{JCSD} / 53-03$

Publication date: November $30^{\text {th }} 2019$

\section{Introduction}

Numbers of cooperatives in Ethiopia were for about 14,453 with total capital 5,126,912,681, whereas, in Tigray total numbers of cooperatives were about 834 , with total capital 216,000,312. (Tesfamariam, 2015). Cooperatives have proven themselves as a resilient and visible business model that can prosper even during difficulties. This success has helped prevent many families and communities from sliding in to poverty" (Kelly, 2012).It is only possible if the group is instilled with trust. Cooperatives are means to maximize incomes of households (Ahikire, et al., 2013).

Studies show that children and women in Ethiopia are affected by hunger and disease because of food insecurity. Ethiopia has been plagued with food insecurity, including famine, for centuries and malnutrition is widespread, particularly amongst children and women (Minnaar, et al., 2013). In addition, women's participation in cooperative activities is less than men; For instance, in Ethiopia number of male participants to female participants in cooperative until 2011 are 5,153,271 to 1,413,423 respectively (Mohammed and Lee, 2015).

The purpose of this study is to explore the role of local food processing women's cooperatives on urban women's empowerment and poverty reduction on members of the cooperatives in Alamata town. Food Processing is altering fresh product from its raw state by changing its form (example. grinding, pureeing), for cooking or baking. In addition to this Washington States Development of Agriculture (2010) defined food processing as the process of any food for sale for human consumption in any manner.

Urban population relies heavily on the purchase of food commodities as compare to rural population (Kobakiwal, 2011). This is because of different factors, such as, urban lifestyles, distance between home and work place, women's workload, that increase the demand for value added foods. Value added foods are foods processed targeting longer shelf life that overcomes the spoilage and losses. Consumers focus on quality of products in relation to processed foods. Quality issues include minimizing the effect of chemical reactions and protect loss of nutrients while preparing the food. Appearance, color, flavor and texture are epicenter for consumers..

The specific Objectives are;-

$>$ To examine competency of urban women in local food processing cooperatives

$>$ To analyze factors affecting local food processing cooperatives

The Conceptual framework of this study includes - institutional factors, demographic factors, economic factors, and, political factors. All besieged the urban women empowerment. This paper is organized as follows; the second section provides methods and materials, area description, data, and the statistical tools used for analysis. 
The third section presented results and discussed. The last section concludes.

\section{Methods and materials}

The researcher uses mixed methods of research approaches. This is because there are both qualitative and quantitative data that provides better understanding of research problem and question than either method by itself (Creswell, 2012). Qualitatively data are collected using unstructured interviews in the participants setting. Quantitatively data are collected, using closed ended questions and numbers to examine the relationship among variables

The study was conducted in Alamata town located in northern Ethiopia around 600km far from Addis Ababa. Its geographical grids are $12^{\circ} 25^{\prime}$ North latitude and $39^{\circ} 33^{\prime}$ East longitude with the elevation of $1520 \mathrm{~m}$ above sea level. The town has a population of 33,198 (CSA, 2008, referred in Gebreegziabher and Tadesse, 2013).

The researcher uses non-probability sampling approach purposely so that the study is feasible. The total units of analysis are 150 . Both primary data from primary sources and secondary data from secondary sources are gathered. Focus group discussion-and Key informant interview are conducted to triangulate the data volubility. The questionnaires consist of mixed items because such instrument format is advisable for it adopts the advantage of both open and closed ended items (Mulu, 2011) Here the researcher uses independent items and contingency items to strengthen the information gathering power of the instruments. The question formats or items are. scaled items with rating scale (Likert scale) and matrix questions, multiple choice items and single choice items

The statistical methods such as descriptive and logistic regression method of analysis are employed to describe the level of urban women empowerment in Local Food Processing Cooperatives. Therefore, binary logistic regression, and simple linear regression are applied to analyze the categorical dependent variables The researcher also uses $T$ tests and $P$ value $\leq 0.05$ to assess the variables level of statistical significance. $T$ test in this study is used to compare empowerment of members before and after cooperative. The researcher uses multicolinearity assumptions to assess the significant level of variables such as types and prices values of houses owned by cooperative members. The assumptions of multi-colinearity with high inter correlation among the independent variables (above .80) indicates the possible of colinearity problems. The second assumptions are tolerance and variance inflation factors (VIF). Value of tolerance $<.20$ and value of VIF $>4.0$ are indicators of multi co linearity problems (Garson, 2012) multi-co linearity can be assessed using variance inflation factor (VIF) with the model: $\mathrm{VIF}_{\mathrm{k}}=\left(1-\mathrm{r}^{2} \mathrm{k}\right)^{-1}$ -

Where: $\mathrm{r}^{2} \mathrm{k}$ - the coefficient of multiple determinations, where $\mathrm{k}$ is regressed on the $\mathrm{P}-2$ remaining variables in the model

- $\quad \mathrm{r}^{2} \mathrm{k}$ - near 1 indicates significant correlation

To evaluate the data Pearson and Spearman's correlation is applied using SPSS v. 20. The researcher determines whether the predictor sizes of household, such as age educational level of the household head, membership duration, and marital status in relation to the empowerment index. Then, the researcher uses a logistic regression model, given by

$\operatorname{Logit}(\mathrm{P})=\operatorname{In}\left(\begin{array}{c}\underline{P} \\ 1-P\end{array}\right)=\beta_{0}+\beta_{1 \mathrm{X} 1}+\beta_{2} \mathrm{X}_{2}+\beta_{3 \mathrm{X} 3}+\ldots \beta_{\mathrm{nXn}}$

Where

$\mathrm{X} 1, \mathrm{X} 2, \mathrm{X} 3 \ldots \mathrm{Xn}$ are the predictor variables age of cooperative member, size of household, educational level of the cooperative member, respectively and $p$ denoted the probability that the household is empowered. And

$\beta_{0}=$ Constant

$\beta_{1}, \beta 2, \beta 3$, are coefficients of Independent variables

In manipulation of binary logistic regression, the assumption taken as a baseline to go through the analysis are statistically significant values of model coefficients, Hosmer - Lemeshow goodness of fit test to be statistically not significant. The interpretation is based on the values of odds ratio in references to observed groups and predicted probabilities.

The researcher uses simple linear regression to analyze the effect of or the relationship between saving habit and health care with the model:

$\mathrm{Y}=\alpha+\beta \mathrm{X}$ :

Where:

Y - Health care probability (Dependent Variable)

$\mathrm{X}$ - Saving (Independent Variable)

$\alpha$ - Constant

$\beta$ - Value of $\mathrm{y}$ when $\mathrm{x}$ is zero, which is also constant.

Gebreegziabher and Tadesse (2011) defined factor analysis as a popular method of analysis used to assess the variation of variables. The researcher finds that PCA is an appropriate model to determine factors that affect women empowerment in local food processing cooperatives. Similarly, Teklehaimanot, et al., (2011) used this 
method to identify factors of cooperatives.

Given $P$ variables $X_{1}, X_{2}, X_{3} \ldots X_{p}$, are measured in $N$ households. The principal components of $P$, that. $Z_{1}$,

$Z_{2}, Z_{3} \ldots Z_{p}$, are uncorrelated linear combinations of $X_{1}, X_{2} \ldots X p$. (the original variable), given as

$$
\begin{aligned}
& Z_{1}=a_{11} X_{1}+a_{12} X_{2}+\ldots+a_{1 p} X_{3 p} \\
& Z_{2}=a_{21} X_{1}+a_{22} X_{2}+\ldots . a_{2 p} X_{p} \\
& Z_{p}=a_{p 1} X_{1}+a_{p 2} X_{2} \ldots a p p X p
\end{aligned}
$$

This equation is expressed as $\mathbf{z}=A x$ where $A=\left(Z_{1}, Z_{2} \ldots Z_{p}\right), X=\left(X_{1}, X_{2} \ldots X_{p}\right) A$ is the matrix of the coefficient

\begin{tabular}{|c|c|c|c|c|c|c|}
\hline & \multicolumn{6}{|c|}{ Test Value $=0$} \\
\hline & \multirow[b]{2}{*}{$\mathrm{T}$} & \multirow[b]{2}{*}{$\mathrm{df}$} & \multirow{2}{*}{$\begin{array}{l}\text { Sig. (2- } \\
\text { tailed) }\end{array}$} & \multirow[b]{2}{*}{ Mean Difference } & \multicolumn{2}{|c|}{$\begin{array}{l}95 \% \text { Confidence Interval of } \\
\text { the Difference }\end{array}$} \\
\hline & & & & & Lower & Upper \\
\hline Age of participants & 21.587 & 49 & .000 & 2.380 & 2.16 & 2.60 \\
\hline . Educational level & 15.598 & 49 & .000 & 2.400 & 2.09 & 2.71 \\
\hline Marital status & 25.303 & 49 & .000 & 2.800 & 2.58 & 3.02 \\
\hline Membership duration & 20.756 & 49 & .000 & 3.900 & 3.52 & 4.28 \\
\hline Family size & 15.749 & 49 & .000 & 1.660 & 1.45 & 1.87 \\
\hline children under age of 18 & 20.405 & 49 & .000 & 1.560 & 1.41 & 1.71 \\
\hline head of household & 28.100 & 49 & .000 & 1.960 & 1.82 & 2.10 \\
\hline
\end{tabular}

\section{Result and discussion}

Table 1 One sample $T$ test for cooperative members' demographic profiles

Source: own survey, 2016

$\mathrm{T}$ test in the Table1 indicates that the variables are statistically significant and the members of cooperatives are statistically different in these variables for $p<.001$. In addition, the standard deviation is less than the mean, which reveals similar information with the $\mathrm{p}$ value.

Cooperative members' age is negatively correlated with educational status and health care. This means aged women are not educated and are exposed to poverty. As a result, they have health care problems. Health care is also negatively correlated with family size. That is large families are exposed to poverty and health care problems. Age of cooperative members is positively correlated with marital status. That is most of aged women are married, but marital status is a negative factor for education. Most married women are illiterate. Education is also positively correlated with training and jewelry ownership. This implies that educated women are active in training and use jewelry assets as saving mechanisms. Jewelry assets are also positively correlated with saving habits. Saving cash income in the form of jewelry assets is advantageous to increase income against unexpected inflation. The statistics also indicates that married women are more active in political election than single women are.

Cooperative membership duration has positive influence up on house ownership and house values. That means the more service they have the more probability to have housed with higher price values. Cash saving habit is positively correlated with livestock ownership, furniture ownership, and nutritional knowledge of cooperative members. This implies that improved saving habit is the major factor for economic empowerment of urban women. House ownership of members has positive correlation with access to energy (water and electricity supply) and values of their houses. This indicates that house ownership is a factor for access to energy and economic empowerment too.

The knowledge, skill and interest (competencies) of cooperative members, are necessities for quality products. The majority of cooperative members revealed that they have adequate knowledge and skills about local food processing. Besides, they show high interest to participate in local food processing cooperatives. The implication of the finding from participants' response is the capability of cooperative members to perform quality product in the cooperative. This is also attention grabbing and profit maximizing factor. Knowledge can enable cooperative members to understand the technical process of local food processing. Skill is indicator for good performance of cooperative members in local food processing cooperatives. Similarly, interest is power for cooperative members to participate in local food processing cooperatives. Medium level of competencies is found in KulgizieLemlem $(10 \%)$ and Mulu and Alefu (18.2) Table4.4 indicates that cooperative members acquired good competencies local food processing. 
Table2. One sample $T$ test for competencies of members in LFPCs

\begin{tabular}{lccccccccc}
\hline & \multicolumn{7}{c}{ Test Value $=0$} \\
\cline { 2 - 10 } & $\mathrm{t}$ & $\mathrm{df}$ & $\begin{array}{l}\text { Sig. } \\
\text { tailed) }\end{array}$ & $\begin{array}{c}\text { (2- MeanDifference 95\% CID } \\
\text { Lower }\end{array}$ & Upper & Mean & SD \\
\hline knowledge in nutrition & 41.169 & 49 & .000 & 3.560 & 3.39 & 3.73 & 3.56 & .611 \\
skills & 40.826 & 49 & .000 & 3.540 & 3.37 & 3.71 & 3.54 & .613 \\
interest in L FPC & 26.438 & 49 & .000 & 3.060 & 2.83 & 3.29 & 3.06 & .818 \\
\hline Sourcel
\end{tabular}

Source: own survey, 2016

The $\mathrm{T}$ test statistics indicates that the variances are not the same in all probabilities. This is because $\mathrm{p}<0.001$ which shows the variables are statistically significant Therefore, the distribution of knowledge, skill, and interest among cooperative members is statistically different. This implies that members of cooperatives have difference in knowledge, skill, and interest. The measures of mean and standard deviation of knowledge, skill, and interest reveals similar concept with the $\mathrm{p}$ value. It shows gap among cooperative members in these variables. The concept of empowerment is inclusive and it is the overall improvement in life. These indicators include generally social, economic, and political improvements. All these indicators are analyzed hereunder up on the members.

Table 3. Paired sample $T$ test for economic and political empowerment of members before and after cooperative

\begin{tabular}{|c|c|c|c|c|c|c|c|c|}
\hline & \multicolumn{5}{|c|}{ Paired Differences } & \multirow[b]{3}{*}{$\mathrm{t}$} & \multirow{3}{*}{\multicolumn{2}{|c|}{$\begin{array}{l}\text { Sig. (2- } \\
\text { df tailed) }\end{array}$}} \\
\hline & \multirow[b]{2}{*}{ Mean } & \multirow[b]{2}{*}{ Std. } & & \multicolumn{2}{|c|}{$95 \%$ CID } & & & \\
\hline & & & Mean & Lower & Upper & & & \\
\hline Livestock ownership & .64 & .485 & .096 & -.652 & -.268 & -4.809 & 49 & .000 \\
\hline Cash saving habit & .94 & .240 & .082 & -.665 & -.335 & -6.093 & 49 & .000 \\
\hline House ownership & .76 & .431 & .067 & -.454 & -.186 & -4.802 & 49 & .000 \\
\hline Health care status & 3.32 & 1.778 & .209 & -1.740 & -.900 & -6.320 & 49 & .000 \\
\hline Political empowerment & .92 & .274 & .101 & .117 & .523 & 3.175 & 49 & .003 \\
\hline
\end{tabular}

Source: own survey, 2016

The paired sample $\mathrm{T}$ test in Table 3 indicates that the variables are statistically significant for $\mathrm{p}<.001$ and the cooperative members are statistically different in these variables. The political empowerment of members has the $\mathrm{p}<.004$ but similar implication in level of significance and variation of the variables.

Customers are asked regarding to their satisfaction level, quality, ingredient, and durability of cooperatives' products. The result $69.6 \%$ from the total consumer-customers are satisfied by services provided in local food processing cooperatives. Comparing the two sexes more males is satisfied than females. The majority of both sex participants (76.6\%) agree up on the durability of Enjera processing cooperatives' products. Likewise, $74 \%$ and $37.8 \%$ of both sexes agreed up on the quality and good ingredient of cooperatives food product respectively. Generally, when more females agree in good ingredients and durability, more males agree on satisfaction and quality of local food processing cooperatives' products. The standard deviations of all data under these participants are smaller than the mean of all participants within these sample sizes that indicates the normal distribution of data among participants. .

Table4. Multi-colinearity results of house ownership

coefficients $^{\text {a }}$

\begin{tabular}{|c|c|c|c|c|c|c|c|c|}
\hline \multirow[b]{2}{*}{ Model } & & \multicolumn{2}{|c|}{$\begin{array}{l}\text { Un standardized } \\
\text { Coefficients }\end{array}$} & \multicolumn{2}{|l|}{$\begin{array}{l}\text { Standardized } \\
\text { Coefficients }\end{array}$} & \multicolumn{3}{|c|}{$\begin{array}{l}\text { Collinearity } \\
\text { Statistics }\end{array}$} \\
\hline & & $\mathrm{B}$ & Std. Error & Beta & $\mathrm{t}$ & Sig. & Tolerance & VIF \\
\hline \multirow{3}{*}{1} & (Constant) & .238 & .070 & & 3.382 & .001 & & \\
\hline & type of house & .120 & .036 & .293 & 3.313 & .002 & .792 & 1.262 \\
\hline & price of house & .392 & .051 & .668 & 7.633 & .000 & .806 & 1.240 \\
\hline
\end{tabular}

a. Dependent Variable: Do you have house after cooperative?

Source: own survey, 2016

The result for types and prices of houses that members' have indicated that there is no multi-collinearity problem and the $p<0.05$, which is statistically significant, at $p<0.003$, and $p<0.001$, respectively. The absence of collinearity problem is identified based on the values of tolerance and Variance Inflation Factor (VIF). Tolerance $>.20$ and VIF $<4.0$ are indicators of absence of multi-collinearity problems (Garson, 2012). Therefore, the variables and the results in figure 1 and 2 are statistically significant. 

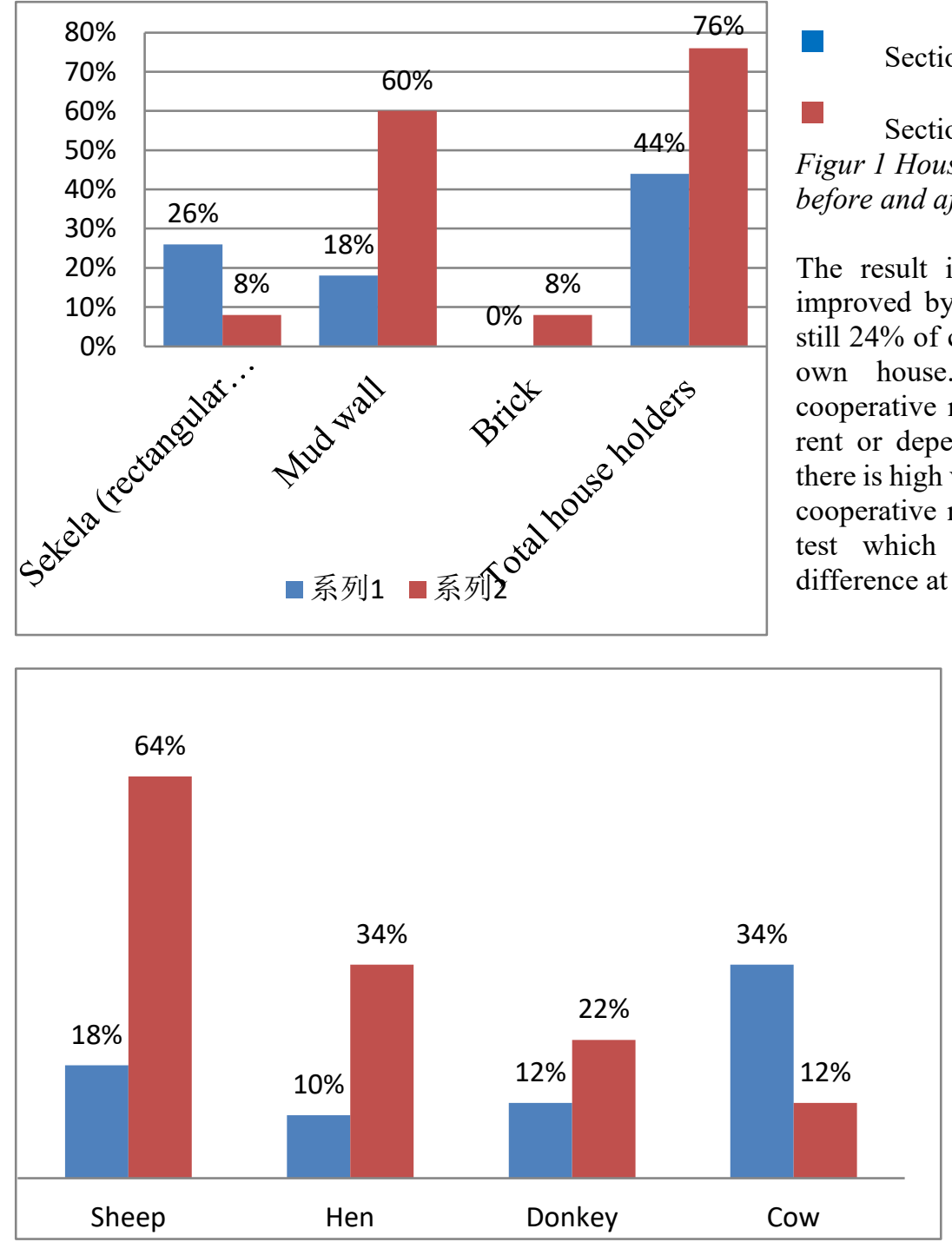

\section{Section 1 - Before cooperative}

Section 2 - After cooperative Figur 1 House type distribution among members before and after cooperative

Source: own survey, 2016

The result indicates that house ownership is improved by $32 \%$ after cooperative. However, still $24 \%$ of cooperative members have not their own house. This indicates that $24 \%$ of cooperative members are living either in house rent or dependent on their family in addition, there is high variation in house ownership among cooperative members. This is checked by the $\mathrm{T}$ test which indicates statistically significant difference at $\mathrm{p}<.001$ indicated on Table 4 .

Figure2 Individual members' livestock ownership before and after cooperative Source: own survey, 2016

The existence of these livestock indicates that the prevalence of urban agriculture in the town. The livestock are parts of indicators of economic empowerment. Except cow, all other livestock are showing increment found in the hands of members after cooperative. People in urban areas are forced to use zero grazing purchasing their foods from the market, which needs much capital. They had cow before cooperative because some of cooperative members were from rural areas that was suitable for keeping of cows. Their value is considered based on their current price for each livestock type. These average values are taken from the market survey of the study area by the researcher. There is huge variation in livestock ownership among cooperative members. This is indicated by the statistically significant difference at $p<.001$ in Table4. The result indicates the overall improvement of members' capital accumulation by increasing numbers of their livestock.

Table5. Age versus livestock ownership of individual members

Variables in the Equation

\begin{tabular}{|c|c|c|c|c|c|c|c|c|c|}
\hline & \multirow[b]{2}{*}{ B } & \multirow[b]{2}{*}{ S.E. } & \multirow[b]{2}{*}{ Wald } & \multirow[b]{2}{*}{ Df } & \multirow[b]{2}{*}{ Sig. } & \multirow[b]{2}{*}{$\operatorname{Exp}(B)$} & \multicolumn{2}{|c|}{ 95\% C.I.for EXP(B) } \\
\hline & & & & & & & & Lower & Upper \\
\hline \multirow{4}{*}{ Step $1^{\mathrm{a}}$} & Age & & & 1.429 & 2 & .490 & & & \\
\hline & Age (1) & .965 & .888 & 1.181 & 1 & .277 & 2.625 & 460 & 14.965 \\
\hline & Age (2) & .523 & .712 & .540 & 1 & .462 & 1.688 & 418 & 6.812 \\
\hline & Constant & .288 & .382 & .568 & 1 & 451 & 1.333 & & \\
\hline
\end{tabular}

a. Variable(s) entered on step 1: Age.

Source: own survey, 2016

The age versus livestock, ownership results of binary logistic regression are summarized in Table5. The age 
group $(1<50,2>50)$ and the referral is having livestock to that of none of it. Hence, age group 1 compare to age group 2 are 2.625 times more likely to have livestock than age group 2. Therefore, the result indicates that, when age increases the probability to have livestock decreases. This reveals that women at older age have the probability to be exposed for poverty. The result indicates livestock ownership improvement because the statistics is based on livestock ownership of members after cooperative.

Table6. Duration in membership versus house ownership Variables in the Equation

\begin{tabular}{|c|c|c|c|c|c|c|c|c|c|}
\hline \multirow{6}{*}{$\begin{array}{l}\text { Step } \\
1^{\text {a }}\end{array}$} & & \multirow[b]{2}{*}{ B } & \multirow[b]{2}{*}{ S.E. } & \multirow[b]{2}{*}{ Wald } & \multirow[b]{2}{*}{ df } & \multirow[b]{2}{*}{ Sig. } & \multirow[b]{2}{*}{$\operatorname{Exp}(B)$} & \multicolumn{2}{|c|}{$\begin{array}{l}\text { 95\% C.I.for } \\
\text { EXP(B) }\end{array}$} \\
\hline & & & & & & & & Lower & Upper \\
\hline & Duration (2) & -2.882 & 1.176 & 6.008 & 1 & .014 & .056 & .006 & .561 \\
\hline & Duration (3) & -4.317 & 1.541 & 7.854 & 1 & .005 & .013 & .001 & .273 \\
\hline & Duration (4) & -2.931 & 1.274 & 5.293 & 1 & .021 & .053 & .004 & .648 \\
\hline & Constant & 3.219 & 1.020 & 9.963 & 1 & .002 & 25.000 & & \\
\hline
\end{tabular}

a. Variable(s) entered on step 1: Duration.

Source: own survey, 2016

Table6 indicates that the variables are statistically significant indicates there is high difference among cooperative members in economic empowerment. The result presents that when membership duration increases the probability to have house, which is indicator of economic empowerment, also slightly increased. The researcher excludes from the table experiences less than six months assumed as duration 1. In addition, the duration of cooperative members was arranged in ranges such as duration 2 [ $>=6$ months $-3 \frac{1}{2}$, years], duration $3\left[3 \frac{1}{2}-7 \frac{1}{2}\right.$ years], and duration 4 [ $7 \frac{1}{2},-11$ years]' membership experience. The first group is $94 \%$ less likely, the second group is $98 \%$ less likely and the third group is $94 \%$ less likely to have house. The statistics indicates that house ownership increases towards the two tips with less likely than the either sides. This V shape economic empowerment indicates the progress after half membership duration that is after eight years' experiences.

Saving habit: - Cooperative members saving habit before and after cooperative are presented in Figure3.

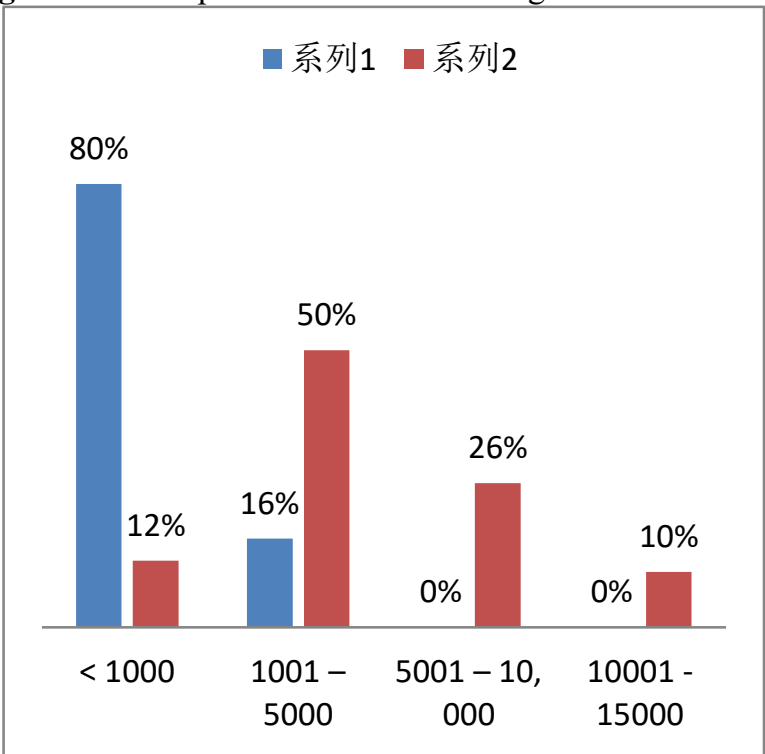

Section 1 - Before cooperative

Section 2 - After cooperative.

Figure3 saving habit of individual cooperative members

Source: own survey, 2016

Amounts of money saved and saving habits have economic influences up on individuals. The result indicates that before cooperative, the majority $(80 \%)$ had saved less than one thousand, and five hundred, which was the maximum limit they could save. However, after cooperative, the maximum saving capacity grows to fifteen thousand and the percentage of lowest saves reduced dramatically to twelve percent. Saving habit is statistically different at $\mathrm{p}<.001$ in Table4.6which reveals the existence of difference among cooperative members in saving habit.

The researcher checks the relation between saving and healthcare in private clinic after cooperative using simple linear regression. The linear regression model, $\mathrm{Y}=\alpha+\beta \mathrm{x}(\mathrm{Y}=.2 .333+1.050 \mathrm{X})$ indicates that saving habit after cooperative is a factor for health care. That means when saving increases there is a probability to increase 
using private clinic too which commonly known as indicator of economic wellbeing and luxury health care.

Table7 Members' political participation

\begin{tabular}{clll}
\hline R. No & Indicators of political empowerment & N (\%) & Yes \\
\hline 1. & Do you want to be a member of any political party? & $36(72 \%)$ & $14(28 \%)$ \\
2. & Allays participate in political elections & $46(92 \%)$ & $4(8 \%)$ \\
3. & You were political candidate representing a party & $20(40 \%)$ & $30(60 \%)$ \\
4. & Are you free and able to get any political information? & $45(90 \%)$ & $5(10 \%)$ \\
\hline
\end{tabular}

Source: own survey, 2016

The objective of this survey is not to evaluate any political party but to investigate the political awareness and competency of cooperative members. The result indicates that they are active in political evaluation and decisionmaking. However, few members are active in representing their political party and there is high variation among the members. The majority evaluate that they can get any political information that help them to participate well. This is indicated in $\mathrm{T}$ test value $\mathrm{p}<$. 004. Therefore, political empowerment is statistically different among cooperative members.

The researcher analyzed factors affecting local food processing cooperatives. These variables affect women empowerment in local food processing cooperatives.

Table8 Total variance explained by all the factors

\begin{tabular}{clll}
$\begin{array}{c}\text { Component } \\
\text { factors }\end{array}$ & \multicolumn{2}{l}{ Initial Eigen values } & $\begin{array}{l}\text { Cumulative } \\
(\%)\end{array}$ \\
\cline { 2 - 4 } & Total & $\begin{array}{l}\text { Variance } \\
(\%)\end{array}$ & 13.102 \\
2. & 3.144 & 13.102 & 24.334 \\
3. & 2.696 & 11.233 & 33.349 \\
4. & 2.164 & 9.015 & 41.173 \\
5. & 1.878 & 7.824 & 48.646 \\
6. & 1.794 & 7.473 & 55.079 \\
7. & 1.544 & 6.433 & 60.703 \\
8. & 1.350 & 5.624 & 65.585 \\
9. & 1.172 & 4.882 & 70.100 \\
10. & 1.084 & 4.515 & 74.232 \\
11. & 0.992 & 4.132 & 78.021 \\
12. & 0.909 & 3.789 & 81.581 \\
& 0.854 & 3.560 & - \\
& - & - & - \\
24. & - & - & - \\
\hline
\end{tabular}

Source: own survey, 2016

Therefore, PCA identified nine factors to analyze from the 24 explanatory variables. The numbers of factors identified from Eigen values greater than one are retained as factors affecting urban women empowerment in local food processing cooperatives. The percentage of variance indicates the contribution of one variable as a factor in relation to the other variables. Accordingly, the first factor is the highest of all other factors and continues up to the lowest factor logically, whereas, cumulative percentage shows the sum total percentages of the variance. 


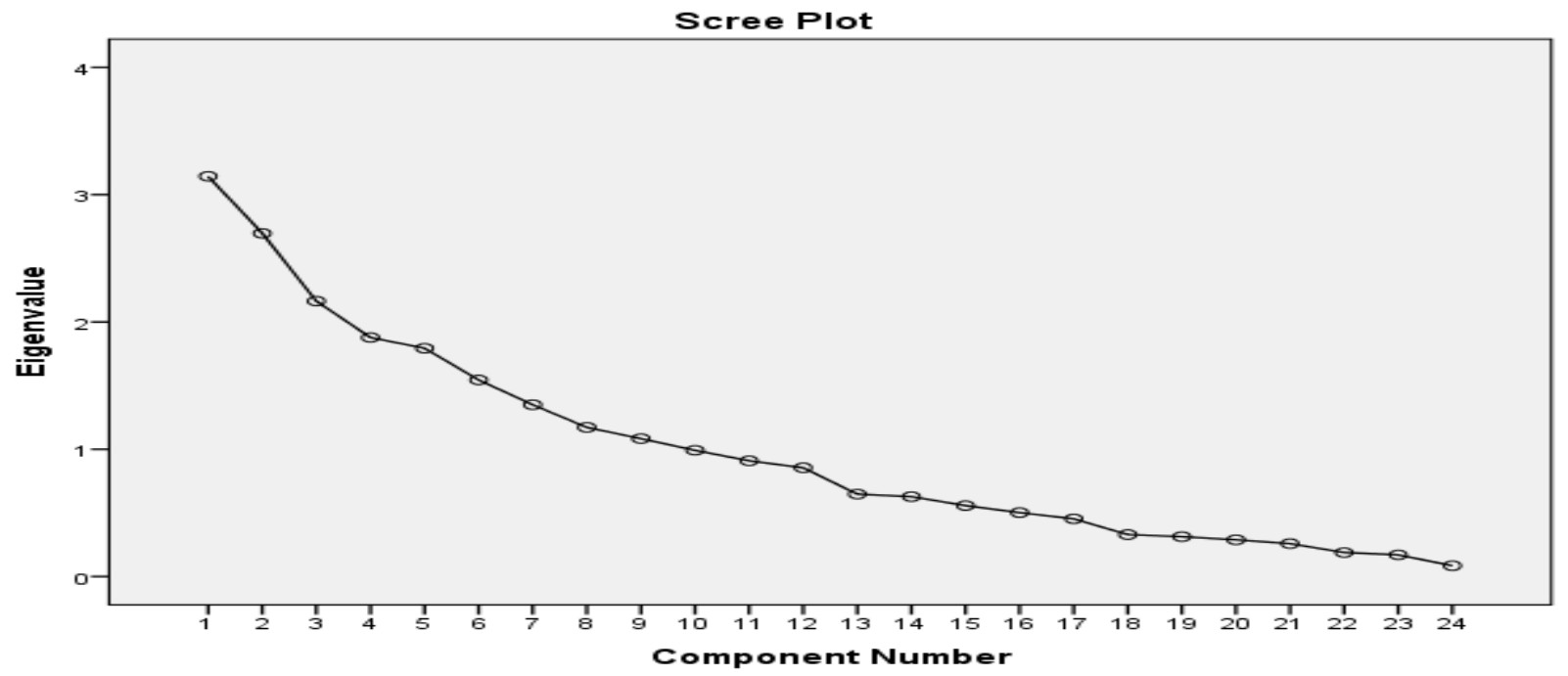

Figure4. Eigen value scree plot

Source: own survey, 2016

A graphic presentation of Eigen values found at factor extraction is shown in the Scree plot Figure4. Each factors variation between variables is expressed based on Eigen values. The Eigen values, percentage of variance of each factor, and the cumulative percentage are also presented inTable4.20. From scree plot and Table8, it is clear that nine factors explained the maximum variability in the factor. Therefore, the nine factors are rotated through varimax rotation and the results found are presented in Table10.

The total variance explained Table4.20indicates nine components or factors, which contribute to 70.10 per cent of the total variance. Hence, all the 24 variables are rotated within these nine factors. Based on the factor loadings of each variable in each factor, the variables are grouped in to these factors. A variable is grouped in that factor, in that it had maximum factor loading in the rotated component matrix given in Figure4. Nine factors are extracted after rotation, as important components (factors) of urban women empowerment in Local Food Processing Cooperatives. The Eigen value less than one or negative is a factor explains less information than a single item will have explained (Leech, et al., 2005). Hence, this study rejects information from such factors.

Table9. KMO and Bartlett's Test

\begin{tabular}{|c|c|c|}
\hline \multicolumn{2}{|c|}{ Kaiser-Meyer-Olkin Measure of Sampling Adequacy } & .529 \\
\hline & Approx. Chi-Square & 357.666 \\
\hline Bartlett's Test of Sphericity & df & 276 \\
\hline & Sig. & .001 \\
\hline
\end{tabular}

Source; own survey, 2016

The factors fitted the standard of KMO value. KMO values varied from scholar to scholar but all agreed on its minimum value to be 0.50 (William et al. 2010). Besides, the Bartlett's test of Sphericity should be significant at $\mathrm{P}<0.05$ and the $\mathrm{p}$ value for these factors is $\mathrm{p}<.002$ in Table4.21. The data for this study provides Kaiser - Mayer - Olkin (KMO) value of 0.529 . This KMO value shows that generally the variables have $53 \%$ in common to warrant a factor analysis. Hence, this KMO value indicates that the items of factors for local food processing cooperatives are adequate for factor analysis because of communality 
Table10. Average score and varimax rotated factor loading for empowerment of urban women in LFPCs

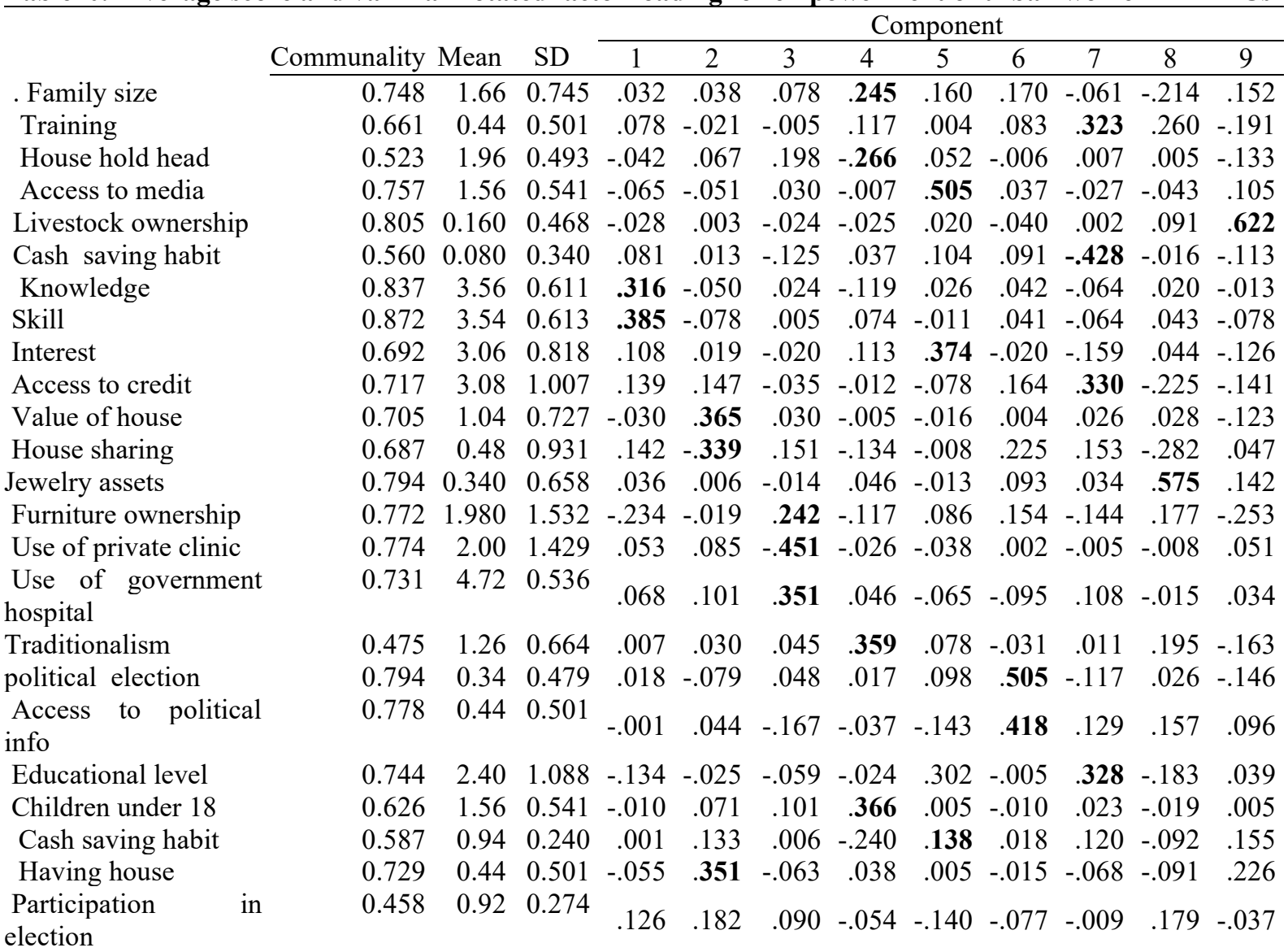

Extraction Method: Principal Component Analysis

Rotation Method: Varimax with Kaiser Normalization

Source: own survey, 2016

Table11. Factor loadings of the identified factors and their names

\begin{tabular}{|c|c|c|c|}
\hline Factor no. & Factor name & Variables & $\begin{array}{l}\text { Factor } \\
\text { loading }\end{array}$ \\
\hline \multirow[t]{2}{*}{1.} & \multirow[t]{2}{*}{ Personal empowerment } & Knowledge & 0.826 \\
\hline & & Skill & 0.921 \\
\hline \multirow[t]{3}{*}{2.} & \multirow[t]{3}{*}{ Access to shelter } & House ownership & 0.801 \\
\hline & & Value of house & 0.745 \\
\hline & & House loading (share) & 0.545 \\
\hline \multirow[t]{2}{*}{3.} & \multirow[t]{2}{*}{ Health care empowerment } & Use in private clinic & 0.858 \\
\hline & & Use in government hospital & 0.731 \\
\hline \multirow[t]{4}{*}{4.} & \multirow[t]{4}{*}{ Decision making } & House hold head & 0.721 \\
\hline & & Family size & 0.609 \\
\hline & & Under age dependency & 0.548 \\
\hline & & Traditionalism & 0.516 \\
\hline \multirow[t]{2}{*}{5.} & \multirow[t]{2}{*}{ Voluntary membership } & Access to media & 0.846 \\
\hline & & Interest for Local Food Processing Cooperative & 0.675 \\
\hline \multirow[t]{2}{*}{6.} & \multirow[t]{2}{*}{ Democracy } & Access to political information & 0.848 \\
\hline & & Participation in election & 0.747 \\
\hline \multirow[t]{4}{*}{7.} & \multirow[t]{4}{*}{ Social empowerment } & Educational level & 0.648 \\
\hline & & Training & 0.599 \\
\hline & & Access to credit & 0.577 \\
\hline & & Cash saving habit & 0.467 \\
\hline 8. & Economic empowerment & Jewelry ownership & 0.807 \\
\hline 9 & Access to small ruminants & Livestock ownership & 0.858 \\
\hline
\end{tabular}

Source: own survey, 2016 
Table11 indicates the items of rotated factors in the varimax matrix. Totally nine factors are identified having maximum percentage variance and high loadings. Loadings and scree plot identify the number of factors. Loadings are Eigen values in the total variance explained table. Thus, from each factor column factors of empowerment having a factor more than 0.5 are selected for factor loading (Teklehaimanot, et al., 2011). The researcher uses only variables with factor loading greater than 0.3 , which is considered as satisfactory. These are grouped and presented in Table4.23. The varimax method makes the squares of loadings of each factor. Hence, the varimax method of factor analysis is computed using Eigen values and percent variation expressed by variables that are categorized in to nine factors presented in Table 11 The loaded variables are further grouped and indicated by numbers like, $1,2,3,4,5,6,7,8$, and 9. The data that concerns to the members are iterated to factor analysis (PCA) until the required KMO value is acquired. The new factors that fulfill the KMO value are named as personal empowerment, access to shelter, health care empowerment, decision-making, voluntary membership, democracy, social empowerment, economic empowerment, and access to keeping ruminants. These new variables are the key values and principles of cooperatives (Mohammed and Lee, 2015). The statistical result of factor analysis (PCA) indicates $\mathrm{p}<.002$ in the Bartlett's Test of Sphericity, which indicates that there is statistically significant difference among cooperative members influenced by the identified factors.

Factor 1: The first factor accounts for 13.102 percent with Eigen value for the factor 3.144 of the total data variability. "These variables imply that the cooperative members need to be equipped with sufficient knowledge and skill " personal empowerment". So they can prepare quality food staff with necessary ingredients and able to increase their income as well.

Factor 2: The percentage of variance expressed by the variables under this factor is 24.33 with the Eigen value 2.69. It is perceived as" access to shelter" ;( Table11). Access to shelter is the pivotal factor or basic need for local food processing cooperatives members.

Factor 3: This factor consists of "health care's empowerment". The variation percentage denoted by this factor is 33.35 with Eigen value of 2.16, (Table11). It is an intervening variable, which has a linkage with income. Medical care mediates the relationship between income and longevity.

Factor 4: This factor is named as "decision making" and has percentage of variance 41.17 and Eigen value 1.89, (Table11). It implies that the decision-making responsibility at household which is also indicator of gender equality Factor 5: This factor accounts for 48.65 percentage of total variance expressed with the Eigen value of 1.79 . It is termed as "voluntary membership". (Table11). Information and interest are the key factors for productivity and empowerment.

Factor 6: This factor is perceived as "democracy". The percentage of variance expressed by this factor is 55.08, and the Eigen value for this factor is 1.54, (Table11). This factor implies the prevalence of political patriotism that can be influenced by the existing political system and the communities' political culture.

Factor 7: This factor accounts for 5.62 percent with Eigen value for the factor 1.35 of the total data variability. It is known as "social affiliation". (Table11).which indicates social empowerment. It is individuals' social activities result for strong social relations and cohesions.

Factor 8: This is named as "economic empowerment", and Table11 indicates that this factor has the total data variability percentage 4.88 with Eigen value of 1.17 . This is the main factor for urban women empowerment that could enable them to escape from economic dependency. Jewelry assets serve as means of saving income in asset form instead of cash saving.

Factor 9: The last factor accounts for 5.51 percent with Eigen value for the factor 1.08 of the total data variability (Table11). The result indicates that "livestock ownership", was found to have low factor loading. This factor was identified as "access to ruminant keeping".

The FGD revealed that opportunities for the profitability of cooperatives are audit support, capacity building via trainings, and access to credit.

The major challenges of their business activities are, Lack of access to market network, absences of center of production, competition with the illegal merchants that did not registered and pay tax. This was because the price reduction by the illegal merchants adversely affected the profitability of the cooperatives. The means to overcome challenges were self-advertising by showing the product, writing letters, improving the product based on the feedback received from customers and so on. The advertisement they used enter and intra urban. Strategies for the sustainability in the business were saving, price determination based on demand and supply, maximum selling with minimum price, and improving quality of production particularly for cooperatives.

\section{Conclusion}

Family size is negatively correlated with education. That means large families have problem to attend education. The distribution of knowledge, skill and interest of cooperative members is statistically different. This absence of homogeneity has positive and negative effects. The positive effect is opportunity for experience sharing. It can be a source of interest conflict adversely. The indicators of members' level of knowledge and skill on local food processing cooperatives are the quality of their product evaluated by their customers. As a result, majority of total 
customers agree that local food processing cooperatives have quality products.

The role of local food processing cooperatives to empower urban women is evaluated based on the observable change on cooperative members' life. The result indicates a sort of progressive change in empowerment. For instance, house ownership, livestock ownership, income accumulation, saving habits, and jewelry ownership shows improvement dramatically. Nevertheless, there are also cooperative members with lack of these assets and living in poverty. Cooperative members are active in political election and have good access to political information, lack of access to market, credit constraints, especially for retailers, and unevenly distributed training, are the major challenges for cooperative members.

In addition, women at older age are exposed to poverty. This result is similar with the finding of Ministry of Labor and Social Affairs of Ethiopia (2012). Simple linear regression indicates as age increase the probability to livestock ownership decreases too.

The factor analysis model identifies nine new variables loaded from 24 iterated variables. The new variables indicate values and principles of cooperatives that enable to achieve their major goals. These variables are personal empowerment, access to shelter, health care empowerment, decision-making, voluntary membership, democracy, social empowerment, economic empowerment, access to ruminant keeping.

\section{Recommendations}

After dealing with the whole studying activities the researcher forwards the following recommendations.

- Education and training should be distributed evenly among cooperative members through integrated functional adult literacy program among all cooperative members equally with supervision and flow up to the tutors.

- $\quad$ Establishment of market network with unions, institutions, and individual merchants is mandatory.

- Access to production center and bank loans for Local Food Processing Cooperatives (LFPCs) should be available.

- Opportunity for access to shelter for individual members of local food processing cooperative should be available. This can enable them to compute with other people. A quarter of Local Food Processing Cooperatives members are living at house rent and dependent on their family. The condominium opportunity can be used as priority for cooperative members. This can also be a tool to provoke working in cooperation for individuals.

- Promotion of special attention for older women is necessary input. The result of this study and the Ministry of Labor and Social Affairs of Ethiopia (2012) indicates that women at older age are exposed for poverty. Therefore, economic empowerment for older women should be given due attention.

- Long-term credit opportunities for small-scale cooperatives and improvement or revision of financial institutes' prerequisites should be given due attention. This is because twenty percent of retailers are exposed to usurers because of the financial institutions' prerequisites. The grouping system of microfinance and credit exposes people to pay extra loans if one of the groups cannot afford the repayment. The master plan prerequisite of national bank and microfinance excludes those who live in house rent or with no master plan. It serves only for those who have their own house or the wellbeing sections of the community, excluding people at lower living standards.

- Designing and implementing values and principles of cooperative sensitive policy is the prerequisite for women empowerment via cooperative activities. Factor analysis identifies personal empowerment, access to shelter, health care empowerment, decision-making, voluntary membership, democracy, social empowerment, and economic empowerment as factors affecting women empowerment in local food processing cooperatives. These factors need to be given due attention at the national policy implementation strategies.

- Personal empowerment of women needs women to develop sense of self-confidence through acquiring and practicing of skill and knowledge within the community. Therefore, policies and strategies of governments should focus on women's capacity building through fairly distributed education and training programs. This also helps women to improve their decision-making capability, be aware for democratic leadership and volunteer membership in the cooperatives.

\section{BIBLIOGRAPHIES}

Ahikire, J.; Kafureeka, L., and Murari - muhwezi (2013) The cooperative movement and the challenge of development: A search for alternative wealth creation and citizen vitality approaches in Uganda, Action aid Uganda, Kampala, Uganda.

Birchall, J. (2003) Rediscovering the cooperative advantage Poverty reduction through self-help, Cooperative Brunch International Labor Office, Switzerland, Geneva.

Creswell, J. W. (2012) Educational Research: planning, conducting, and evaluating qualitative and quantitative 
research, $4^{\text {th }}$ edition, Edwards Brothers, Inc. Boston, USA.

www.ilo.org/coopafrica (Accessed on October 19, 2015).

Garson, D, G. (2012) Testing Statistical Assumptions. Book Series 274, Statistical Publishing Associates, North Carolina, USA.

Gebreegziabher, K., and Tadesse, T. (2013) Risk Perception and Management in Smallholder dairy farming in Tigray, Northern Ethiopia, Journal of Risk Research, 17(3): 367 - 381.

http://www.tandfonline.com/action/journalInformation?journalCode=rjrr20(Accessed on May 23, 2016).

Kelly, N. (2012) ICA fact sheet - UN International Year of Co - operatives, the International Cooperatives Alliance (ICA), 150, Route de Femey, Geneva, Switzerland.

www.2012.coop (Accessed on 10December 13, 2015)

Kobakiwal, Q. A. (2011) The Place of Urban and Peri-Urban Agriculture (UPA) in National Food Security Programs, FAO, Rome, Italy.

Leech, N. L., Barrett, K. C., and Morgan, G. A. (2005) SPSS for Intermediate Statistic Use and Interpretation. Statistic, $3^{\text {rd }}$ edition, Lawrence Erlbaum Associates Inc. Mahwah, New Jersey 07430, London, UK

Ministry of Labor and Social Affairs (2012) Gender mainstreaming manual for Labor and Social Affairs Sector, Addis Ababa, Ethiopia.

Minnaar, A., Taylor, J. R. N., Haggblade, S., Kabasa, J. D. and Ojijo, N. K. O. (2013) Capacity Development for Modernizing African Food Systems (MAFS) Working Paper, MAFS Working Paper No. 2, Modernizing African Food Systems (MAFS) Consortium, USA.

Mohammed, N., and Lee, B., W. (2015) Role of Cooperatives in Rural Development, the Case of South Nations Nationalities and People Region, Ethiopian Science Journal of Business and Management, 3(4): 102-108. http://www.sciencepublishinggroup.com/j/sjbm (Accessed on December 21, 2015).

Mtonga, E., M. (2012) Cooperatives and Market access in Zambia, Discussion paper, Lusaka, Zambia. http://www.firstfairtradetownusa.org/fair-trade/ (Accessed on September 10, 2015).

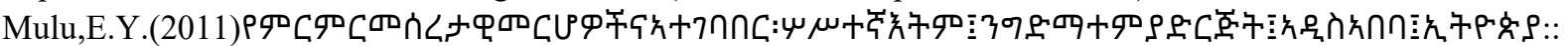

Teklehaimanot, A., Bahal, R., Mathur, V.C., Vijayaragavan,K.,Mahajan, V.K., and Padaria,R.N. (2011) Determinants of Agricultural Marketing Cooperatives in India,PusaAgriscience, 34(1): 113 - 120.

Tesfamariam, K., (2015) Savings and Credit Cooperatives in Ethiopia: Development, Challenges and Proposed Intervention, International Journal of Cooperative Studies, 4(1), 1-8.

Washington State Development of Agriculture (2010) "Food processing "Small farm and direct marketing Hand Book, Washington DC, U.S.A 